\title{
SILVICULTURAL PERFORMANCE OF EUCALIPTUS AND ANIMAL BEHAVIOR IN A SILVOPASTORAL SYSTEM
}

\author{
DESEMPENHO SILVICULTURAL DE EUCALIPTO E COMPORTAMENTO ANIMAL \\ EM SISTEMA SILVIPASTORIL
}

\author{
Giselle Feliciani BARBOSA ${ }^{1}$; Wolff Camargo MARQUES FILHO ${ }^{2}$; \\ Simone Cândido ENSINAS ${ }^{1}$; Daiane Cristina FLÁVIO³; Isabela Machado de Oliveira LIMA \\ Maiara Fernanda Garcia SILVA ${ }^{3}$; Gabriela da Silva FREITAS ${ }^{3}$ \\ 1. Ph.D Professor, State University of Mato Grosso do Sul-UEMS, Cassilândia, Mato Grosso do Sul, Brazil; giselle.barbosa@uems.br; \\ 2. Ph.D Professor, Federal Institute of the Northern Minas Gerais-IFNMG, Salinas, Minas Gerais, Brazil; 3. Graduation student, UEMS, \\ Cassilândia, Mato Grosso do Sul; Brazil.
}

\begin{abstract}
Silvopastoral system, in which trees and forage species are grown in the same area together with animals, has emerged as a sustainable alternative of agricultural production systems. However, information on different silvicultural arrangements and combinations of forest, animal and grazing components in this system are still scarce. Thus, this study followed the silvicultural performance of the forest component (Eucalyptus urophylla $\mathrm{x}$ E. grandis, eucalyptus hybrid, clone I-144) under different population arrangements in a silvopastoral system through periodic dendrometric evaluations and determined the impact of animal component (Nellore females) on tree development and ingestive behavior of animals subjected to rotational grazing in Urochloa brizantha cv. Marandu. The study was conducted at Agropecuária Ouro Branco, located in Bandeirantes, MS, Brazil. Total height, diameter at breast height, and wood volume per hectare were evaluated in three- and five-row ranks. To indicate plant growth, the current and average annual increments were calculated. Animal behavior was evaluated based on the periodic observation of 15 animals randomly selected in the lot. The initial performance of forest component was satisfactory in both populations, but growth indicators indicated greater current and average annual increments in the five-row rank. The presence of forest component does not interfere with the ingestive behavior and wellbeing of animals in the silvopastoral system, as well as, the presence of animal component does not interfere in the plants silvicultural development.
\end{abstract}

KEYWORDS: Agroforestry systems. Population arrangement. Ingestive behavior. Beef cattle.

\section{INTRODUCTION}

The advancement of knowledge on different systems capable of composing and sustaining life on Earth has enabled new techniques to increase food supply and improve human nutrition (ASSAD; ALMEIDA, 2004). However, to produce food to meet population needs, some production systems, such as monoculture and extensive livestock farming, have promoted serious environmental imbalances.

Among the main problems of these production models are the high levels of soil degradation and emission of polluting gases, which promote ozone layer destabilization, contamination of potable and non-potable water sources, and suppression of fauna and flora, often changing completely the ecological cycle of a given region, culminating in the degradation of natural resources and consequent unsustainability of agricultural systems (MACEDO, 2009).

Agroforestry systems are among the agricultural production systems considered as sustainable, consisting of land use systems in which trees grow in association with other activities such as livestock and pasture or other crop production. These systems have great environmental importance due to their characteristics of conservation and maintenance of soil fertility, fixation of carbon and organic matter, health and animal wellbeing, microclimatic modifications, among other beneficial factors (OLIVEIRA et al., 2007).

The silvopastoral system is one of the agroforestry systems in which tree and forage species are grown in the same area with ruminant animals. This system represents a way of using the area where both activities are associated to generate a complementary production (VARELLA et al., 2009).

In addition to the benefits of forest production, agroforestry systems contribute to carbon sequestration and mitigation of the emission of nitrous oxide $\left(\mathrm{N}_{2} \mathrm{O}\right)$ and methane $\left(\mathrm{CH}_{4}\right)$ produced by ruminants and important to the so-called greenhouse effect. In this system, the so-called "green cattle" are reared due to a reduction of the 
harmful effects of gases produced by animals (PORFÍRIO-DA-SILVA et al., 2009).

According to Ferreira (2005), under conditions of intense heat, cattle alter their posture to take advantage of heat dissipation by wind, reducing movement, ingesting less food, and having a shorter period destined to rumination, which affects the conversion to meat and milk.

In this context, Porfírio-da-Silva et al. (2009) observed an improvement in animal performance by the shading provided by the silvopastoral system, as it increased comfort and protection of animals and pastures. Moreover, natural shading of trees assists in eliminating investments for constructions of artificial shades for animals. For the success of the silvopastoral system, the implantation should consider some aspects such as: spacing; population arrangement; canopy size of the implanted species; the number, direction and positioning of tree rows; the forage species used; among others.

According to Marques Filho et al. (2017), tree position in the arrangement influences the development of the forest component, with plants of the central row show less development when compared to those in the lateral rows. According to the authors, wood volume per plant is highly influenced by height and diameter at breast height,
BARBOSA, G. F. et al.

and the greater the area per plant and the greater the luminosity are, the greater the wood productivity.

According to Porfírio-da-Silva et al. (2012), the evaluation of components in an integration system is essential to reach its potentiality. In this context, this study evaluated the influence of different arrangements of forest component in a silvopastoral system on the initial growth and development of eucalyptus, as well determined the impact of inserting the animal component on tree development and ingestive behavior of animals subjected to grazing.

\section{MATERIAL AND METHODS}

The study was done in the Agropecuária Ouro Branco, located in Bandeirantes, Mato Grosso

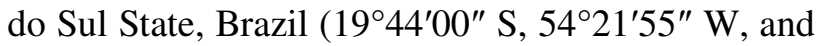
$655 \mathrm{~m}$ of average altitude), in a newly implanted area under silvopastoral system, which had the following components after its complete setup: eucalyptus hybrid (E. urophylla $\mathrm{x}$ E. grandis, clone I-144), pasture (Urochloa brizantha cv. Marandu), and cattle (Nellore females). According to Köppen (1948), regional climate is classified as a rainy tropical climate (Aw) with a dry winter. Meteorological data for the experimental period are shown in Figure 1.

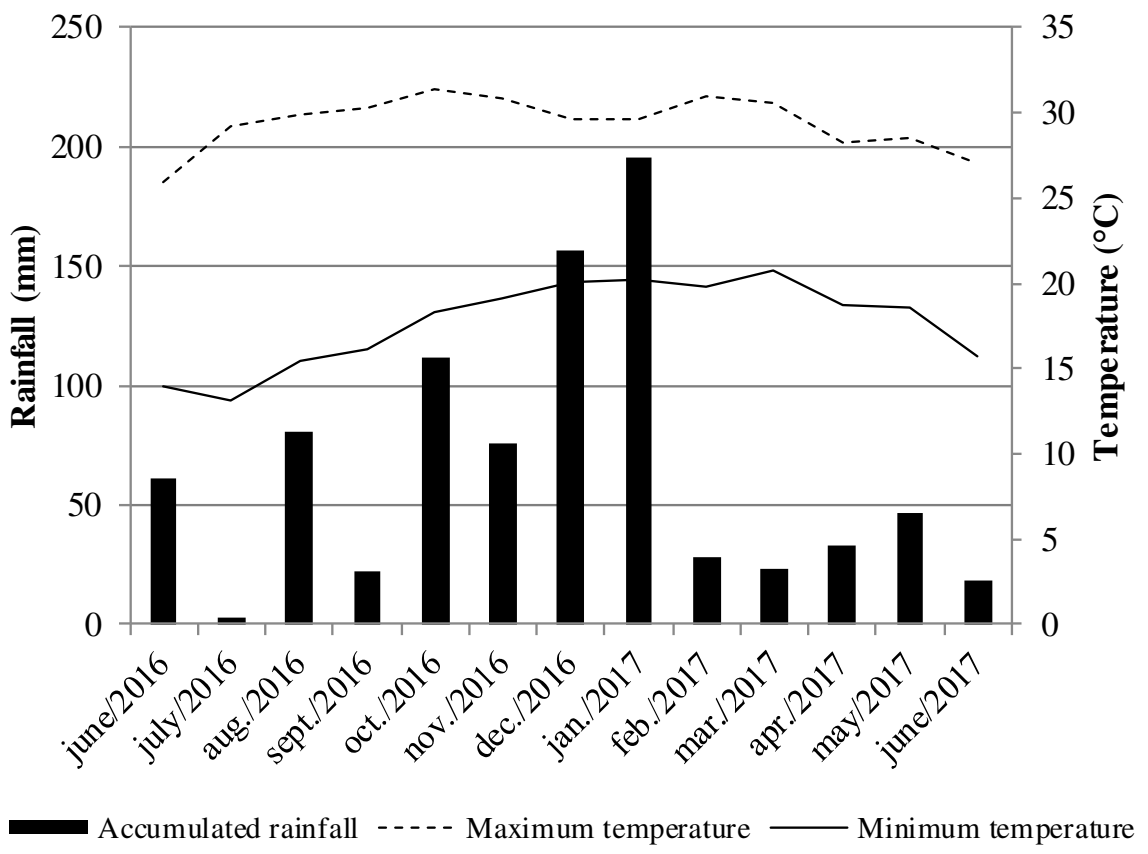

Figure 1. Accumulated rainfall and maximum and minimum temperatures from June 2016 to June 2017. Bandeirantes, Mato Grosso do Sul, Brazil, 2017 (SOURCE: INMET/SEPAF/ AGRAER/CEMTECMS, 2017). 
The area consists of 200 hectares where eucalyptus clones, homogeneously arranged in the east-west direction, were planted in the spring of 2015/2016 in population arrangements of three and five rows with spacing of $1.5 \mathrm{~m}$ between rows and $2.0 \mathrm{~m}$ between plants, 20.0 and 18.5 meters apart, totaling $15.2 \mathrm{~m}^{2}$ plant $^{-1}\left(652\right.$ plants ha $\left.{ }^{-1}\right)$ and $9.8 \mathrm{~m}^{2}$ plant $^{-1}\left(1020\right.$ plants ha $\left.{ }^{-1}\right)$, respectively.

In the newly installed area, 12 experimental plots of $200 \mathrm{~m}^{2}$ were delimited for each population arrangement and plants from each plot were considered as plants of the useful area and evaluated throughout the experimental period.

Development and initial growth of trees were followed by means of periodic dendrometric evaluations at six, nine, twelve, fifteen, and eighteen months of age. Total height $(\mathrm{H})$ of trees was estimated by using a clinometer (Haglöf ${ }^{\circledR}$ ) and the diameter at breast height (DBH) was measured with a diametric tape, allowing calculating wood volume per plant and per hectare (PORFÍRIO-DA-SILVA et al., 2009).

In order to indicate plant growth, the current (CAI) and mean (MAI) annual increments based on the dendrometric evaluations performed over the period were calculated, as Equations (1) and (2):

$$
\begin{aligned}
& \mathrm{CAI}=\frac{(v t+1)-v t}{(t+1)-t} \\
& \mathrm{MAI}=\frac{v t+1}{t}
\end{aligned}
$$

where $v t$ is the volume at beginning of the period, $v t$ +1 is the volume at the end of the period, $t$ is the age, and $t+1$ is the age at end of the period.

When eucalyptus plants reached, on average, seven meters in height, the animal component was introduced into the system. Healthy, female Nellore cattle, with an average age of 26 months and average live weight of around $300 \mathrm{~kg}$, were subjected to rotational grazing on pickets with
50 hectares of $U$. brizantha cv. Marandu with mineral supplementation and water ad libitum.

Monthly, the ingestive behavior and behavioral indicators of the wellbeing of 15 animals randomly selected in the lot and previously adapted to the evaluation methods were evaluated through individual observation by five trained observers, who remained distant from the animals, mounted on horseback and equipped with binoculars, radio communicator, and notebook clipboard. Animals were bilaterally identified in the rump and thoracolumbar regions with a red spray paint (Topmarker ${ }^{\circledR}$ ). At each evaluation, grazing and feeding periods, average idling time, movement, and rumination, and frequency of defecation and urination were determined by observing the animals for eight hours in the pasture.

Dendrometric data were submitted to statistical analysis of variance and, when significant, averages were compared by the t-test $(\mathrm{p} \leq 0.05)$ using the ASSISTAT - Statistical Assistance software version 7.7 (SILVA; AZEVEDO, 2014).

\section{RESULTS AND DISCUSSION}

Table 1 shows the results of average height for plants in three- and five-row ranks. In all evaluations, except at twelve months of age, plants in five-row rank presented greater plant height when compared to those in three-row rank, differing statistically from each other.

Oliveira et al. (2009) observed the greatest plant heights in denser plantings, which may be due to plant competition, which could explain the significance observed for plant height as a function of the available area per plant in each population arrangement. However, Reiner, Silveira, and Szabo (2011) observed no difference in plant height for different planting spacings during the first and second years of cultivation of E. dunnii.

Table 1. Plant height of eucalyptus hybrid clone I-144, in three- (R3) and five-row (R5) population ranks in a

\begin{tabular}{|c|c|c|c|c|c|}
\hline \multirow{2}{*}{ Treatment } & \multicolumn{5}{|c|}{ Plant height (m) } \\
\hline & 6 months & 9 months & 12 months & 15 months & 18 months \\
\hline R3 & $1.7 \mathrm{~b}$ & $2.5 \mathrm{~b}$ & $3.1 \mathrm{a}$ & $6.9 \mathrm{~b}$ & $7.1 \mathrm{~b}$ \\
\hline R5 & $1.9 \mathrm{a}$ & $2.9 \mathrm{a}$ & $4.1 \mathrm{a}$ & $7.6 \mathrm{a}$ & $8.1 \mathrm{a}$ \\
\hline $\mathrm{F}$ test & $20.3^{* *}$ & $29.4^{* *}$ & $1.9^{\mathrm{ns}}$ & $20.8^{* *}$ & $44.2^{* * *}$ \\
\hline $\operatorname{LSD}^{(1)}$ & 0.09 & 0.12 & 0.15 & 0.28 & 0.30 \\
\hline Average & 1.7 & 2.7 & 4.0 & 7.2 & 8.4 \\
\hline $\mathrm{CV}^{(2)}(\%)$ & 12.39 & 11.30 & 9.39 & 9.47 & 8.83 \\
\hline
\end{tabular}
silvopastoral system. Bandeirantes, Mato Grosso do Sul, Brazil, 2017.

** Significant $(\mathrm{p} \leq 0.01)$ and ${ }^{\mathrm{n}}$ not significant by the $\mathrm{F}$ test. Average followed by the same letter in the column do not differ from each other by the t-test $(\mathrm{p} \leq 0.05) .{ }^{(1)} \mathrm{LSD}$ : least significant difference. ${ }^{(2)} \mathrm{CV}$ : coefficient of variation. 
Among all evaluations presented in Table 2, related to the comparison between averages of the diameter at breast height of plants arranged in three and five rows, statistical difference was observed only at nine months, in which plants arranged in five rows presented a greater diameter in relation to plants arranged in three rows.

Faria et al. (2013) found an average diameter at breast height of $6.2 \mathrm{~cm}$ in plants of $E$. urophylla $\mathrm{x}$ E. grandis at 18 months, which is lower when compared to the one found in our study (7.3 $\mathrm{cm}$ ). Vieira and Valdir (2011) observed in a study with the same species and age an average diameter at breast height greater than $8.0 \mathrm{~cm}$. Thus, the results obtained in this study are close to the findings in the literature.

Oliveira et al. (2009) observed a significant interaction for plant height and diameter at breast height in eucalyptus hybrid, E. camaldulensis x $E$. urophylla, at eighteen months after planting, indicating possible differences between plants from different arrangements as plant age increased.

Kruschewsky et al. (2007) stated that, from the second year onwards, the greater the useful area of the arrangement, the greater the $\mathrm{DBH}$; in addition, as time passes on, the growth rate decreases in smaller spacings. These authors also noticed larger individual production at wider spacings; and, up to 67 months, stand productivity had more influence from the number of individuals per area than from the structural arrangement.

In the evaluations of wood volume per hectare (Table 3), no statistical differences were found between plants arranged in three and five rows at six, nine, fifteen, and eighteen months of age. Significant differences were observed only at twelve months of age when plants arranged in three rows presented the greatest volumes. Oliveira et al. (2009) observed no effect of spatial arrangements at 18 months after planting on plant volume. Kruschewsky et al. (2007) found no differences between arrangements $(3.33 \times 2.0 \mathrm{~m}, 3.33 \times 3.0 \mathrm{~m}$, $5.0 \times 2.0 \mathrm{~m}$, and $10.0 \times 2.0 \mathrm{~m}$ ) and volume at 18 months of age, but the greatest volume was observed in the widest arrangement $(10.0 \times 2.0 \mathrm{~m})$ at 38 months after planting.

Table 2. Diameter at breast height (DBH) of eucalyptus hybrid clone I-144, in three- (R3) and five-row (R5) population ranks in a silvopastoral system. Bandeirantes, Mato Grosso do Sul, Brazil, 2017.

\begin{tabular}{|c|c|c|c|c|}
\hline \multirow{2}{*}{ Treatment } & \multicolumn{4}{|c|}{$\mathrm{DBH}(\mathrm{cm})$} \\
\hline & 9 months & 12 months & 15 months & 18 months \\
\hline R3 & $2.5 \mathrm{~b}$ & $3.1 \mathrm{a}$ & $6.1 \mathrm{a}$ & $7.2 \mathrm{a}$ \\
\hline R5 & $2.7 \mathrm{a}$ & $4.2 \mathrm{a}$ & $6.3 \mathrm{a}$ & $7.5 \mathrm{a}$ \\
\hline $\mathrm{F}$ test & $8.2^{* *}$ & $4.0^{\mathrm{ns}}$ & $1.0^{\mathrm{ns}}$ & $2.2^{\mathrm{ns}}$ \\
\hline $\operatorname{LSD}^{(1)}$ & 0.15 & 0.19 & 0.30 & 0.30 \\
\hline Average & 2.6 & 4.0 & 6.2 & 7.3 \\
\hline $\mathrm{CV}^{(2)}(\%)$ & 14.47 & 11.45 & 11.62 & 9.93 \\
\hline
\end{tabular}

** Significant $(\mathrm{p} \leq 0.01)$ and ${ }^{\mathrm{ns}}$ not significant by the $\mathrm{F}$ test. Averages followed by the same letter in the column do not differ from each other by the t-test $(\mathrm{p} \leq 0.05) .{ }^{(1)} \mathrm{LSD}$ : least significant difference. ${ }^{(2)} \mathrm{CV}$ : coefficient of variation.

Table 3. Wood volume of eucalyptus hybrid clone I-144, in three- (R3) and five-row (R5) population ranks in a silvopastoral system. Bandeirantes, Mato Grosso do Sul, Brazil, 2017.

\begin{tabular}{lcccc}
\hline \multirow{2}{*}{ Treatment } & \multicolumn{4}{c}{ Wood volume $\left(\mathrm{m}^{3} \mathrm{ha}^{-1}\right)$} \\
\cline { 2 - 5 } & 9 months & 12 months & 15 months & 18 months \\
\hline R3 & $0.6 \mathrm{a}$ & $2.1 \mathrm{a}$ & $8.0 \mathrm{a}$ & $12.6 \mathrm{a}$ \\
R5 & $0.6 \mathrm{a}$ & $1.8 \mathrm{~b}$ & $7.4 \mathrm{a}$ & $12.1 \mathrm{a}$ \\
F test & $2.7^{\text {ns }}$ & $12.1^{* *}$ & $3.0^{\text {ns }}$ & $1.3^{\text {ns }}$ \\
LSD $^{(1)}$ & 0.06 & 0.17 & 0.67 & 0.97 \\
Average & 0.6 & 1.9 & 7.7 & 12.4 \\
CV & $(\%)$ & 21.43 & 21.01 & 19.13 \\
\hline
\end{tabular}

** Significant $(\mathrm{p} \leq 0.01)$ and ${ }^{\mathrm{ns}}$ not significant by the $\mathrm{F}$ test. Averages followed by the same letter in the column do not differ from each other by the $\mathrm{t}$-test $(\mathrm{p} \leq 0.05)$. ${ }^{(1)} \mathrm{LSD}$ : least significant difference. ${ }^{(2)} \mathrm{CV}$ : coefficient of variation.

Figure 2 shows that for both current and mean annual increments, plants arranged in five rows presented the greater averages when compared to plants arranged in three rows, indicating the greatest plant growth in the area in the same period. 


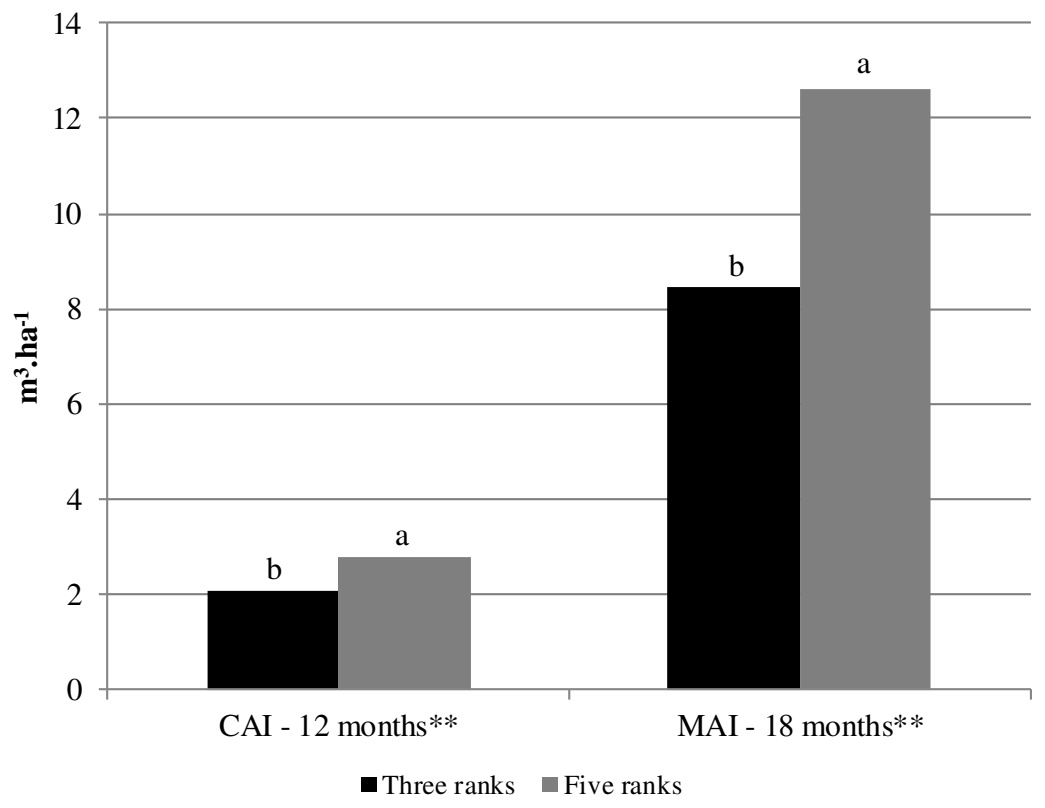

Figure 2. Current (CAI) and mean (MAI) annual increments of eucalyptus hybrid clone I-144, in three- (R3) and five-row (R5) population ranks in a silvopastoral system. Bandeirantes, Mato Grosso do Sul, Brazil, 2017. ** Significant $(\mathrm{p} \leq 0.01)$ by the $\mathrm{F}$ test. Averages followed by the same letter do not differ from each other by the t-test $(\mathrm{p} \leq 0.05)$.

The results of the ingestive behavior of animal component are shown in Table 4. The predominant period spent by animals for grazing in the evaluated lot occurred between 10 and 18 hours, thus encompassing the times of greatest solar incidence and higher temperatures, which is not generally observed in animals evaluated under extensive production in conventional systems of livestock production (ZANINE; SANTOS; FERREIRA, 2006; THUROW et al., 2009).

A shorter grazing time, associated with a thermal sensation of microclimate promoted by a silvopastoral system, is related to a lower animal energy demand. These animals do not expend energy for body thermal regulation, a state denominated zone of thermal comfort, culminating with lower feed intake per animal, which is converted into a greater productivity (BARBOSA, SILVA, 1995, PERISSINOTO et al., 2009). Consequently, lower grass consumption by animals per day reflects in a higher forage availability per hectare, which positively influences the stocking rate, being possible to insert the greater number of animals per hectare (PACIULLO et al., 2009; MARQUES FILHO et al., 2017).

The behavior observed in this experiment regarding grazing and feeding time of animals was different from the findings of Marques Filho et al. (2017) in a silvopastoral system, but with eucalyptus plants at seven years of age. However, longer rumination and idling periods were observed in this study when compared to those observed by them. The predominant rumination period in this study occurred between 7 and 10 hours in the morning.

Rumination is the period in which animals are in the process of digesting the food, and longer time destined to this purpose is related to numerous factors (ZANINE; SANTOS; FERREIRA, 2006) such as food digestibility. Because it is an existing pasture and based on the bromatological analysis of this study, the time spent for rumination is the result of grass quality at the initial phase of the production system.

The time the animals stay idling is directly related to environmental comfort, animal wellbeing, and food quality. These aspects guarantee the animal time to express its natural behavior and destine a minimum time to fattening, with less impact on life quality and behavioral indicators of animal wellbeing (GLASER, 2008).

The behavior expressed behavioral indicators of wellbeing and productive parameters of the animals, such as defecation and urination frequency, were similar to those observed by Marques Filho et al. (2017) in a silvopastoral system arranged with three rows. In all evaluations, about $34 \%$ of the animals presented estrus expression. 
Table 4. Averages of the daily period of feeding, grazing, idling, rumination, movement, and defecation and urination frequency, and grazing mode in a silvopastoral system. Bandeirantes, Mato Grosso do Sul, Brazil, 2017.

\begin{tabular}{lcccc}
\hline \multicolumn{5}{c}{ Daily period (hour) } \\
\hline Month & Feeding & Grazing ${ }^{(1)}$ & Standing idling & Lying idling \\
\hline February & 0.58 & 6.19 & 0.42 & 0.41 \\
March & 0.69 & 6.39 & 0.38 & 0.39 \\
April & 0.63 & 6.47 & 0.32 & 0.37 \\
May & 0.55 & 6.48 & 0.30 & 0.38 \\
Average ( \pm SD) ${ }^{(2)}$ & $0.61( \pm 0.06)$ & $6.38( \pm 0.13)$ & $0.36( \pm 0.06)$ & $0.39( \pm 0.02)$ \\
\hline \multicolumn{5}{c}{ Daily period (hour) } \\
\hline Month & Standing rumination & Laying rumination & Walking close & Walking away \\
\hline February & 0.34 & 0.88 & 0.25 & 0.54 \\
March & 0.33 & 0.90 & 0.22 & 0.49 \\
April & 0.39 & 0.99 & 0.15 & 0.32 \\
May & 0.39 & 1.02 & 0.13 & 0.28 \\
Average $( \pm \mathrm{SD}){ }^{(2)}$ & $0.36( \pm 0.03)$ & $0.95( \pm 0.07)$ & $0.19( \pm 0.06)$ & $0.41( \pm 0.13)$ \\
\hline \multicolumn{5}{c}{ Daily period (hour) } \\
Month & Moving around & Attention/alert & Defection & Frequency \\
\hline February & 0.26 & 0.18 & 4.70 & Urination \\
March & 0.21 & 0.13 & 4.10 & 3.90 \\
April & 0.18 & 0.10 & 3.50 & 3.80 \\
May & 0.19 & 0.10 & 3.30 & 3.50 \\
Average $( \pm \mathrm{SD}){ }^{(2)}$ & $0.21( \pm 0.04)$ & $0.13( \pm 0.04)$ & $3.90( \pm 0.63)$ & $3.70( \pm 0.18)$ \\
\hline (1) $^{(1)}$ Grazing mode in a lot with regular movements and close to leisure areas and dormitory. ${ }^{(2)}$ SD: standard deviation.
\end{tabular}

In addition, during grazing period, the absence of pruning in eucalyptus trees did not inhibit the transposition of rows and ranks by animals during grass intake or cause changes in the behavioral indicators of wellbeing, which did not affect animal weight gain nor caused significant damage to trees. This observation, combined with the other variables studied here, is similar to the ingestive behavior and grazing mode observed in previous studies when the forest component was pruned or trees were older than seven years (MARQUES FILHO et al., 2017).

\section{CONCLUSIONS}

The initial performance of forest component, both in three- and five-row ranks, under the adopted spacing between plants, was satisfactory. However, growth indicators show greater current and average annual increments in plants arranged in five rows.
The presence of forest component does not interfere with the ingestive behavior and wellbeing of animals in the silvopastoral system, as well as, the presence of animal component does not interfere in the plants silvicultural development.

\section{ACKNOWLEDGEMENTS}

The authors acknowledge the owners, managers and employees of the Agropecuária Ouro Branco, a company of the Italian Group Brazzale, for the support and granted financial assistance for the execution of this research; and the Universidade Estadual do Mato Grosso do Sul (UEMS) and the Conselho Nacional de Desenvolvimento Científico e Tecnológico $(\mathrm{CNPq})$ for the scholarship granted to the fourth author.

Research authorized by the Ethics Committee on Animals Use of State University of Mato Grosso do Sul - opinion number 002/2016.

RESUMO: O sistema silvipastoril, onde espécies arbóreas e forrageiras são cultivadas em uma mesma área, conjuntamente com o componente animal, vem se despontando como uma alternativa sustentável de sistemas de produção agrícola, no entanto, informações sobre os diferentes arranjos silviculturais e 
combinações dos componentes arbóreo, animal e pastagem no sistema ainda são incipientes. Assim, este estudo teve como objetivo acompanhar o desenvolvimento inicial do componente florestal (Eucalyptus urophylla x $E$. grandis, híbrido de eucalipto, clone I-144), em diferentes arranjos populacionais, em sistema silvipastoril, por meio de avaliações dendrométricas periódicas; e, determinar o impacto da inserção do componente animal (fêmeas da raça Nelore) sobre o desenvolvimento das árvores e sobre o comportamento ingestivo dos animais submetidos ao pastejo rotacionado em Urochloa brizantha cv. Marandu. O estudo foi realizado na Agropecuária Ouro Branco, situada em Bandeirantes, MS. Tanto nos renques de três, como no de cinco fileiras, foram avaliados a altura total $(\mathrm{H})$, diâmetro a altura do peito (DAP) e volume de madeira por hectare. Para indicar o crescimento das plantas, foram calculados o Incremento Corrente Anual (ICA) e o Incremento Médio Anual (IMA). O comportamento dos animais foi avaliado baseado na observação periódica de 15 animais selecionados aleatoriamente no lote. Verificou-se que o desempenho inicial do componente arbóreo, em ambos os arranjos populacionais, mostrou-se satisfatório, no entanto, os indicadores de crescimento, apontam para um maior incremento corrente e médio anual nas plantas dos renques com cinco fileiras. A presença do componente arbóreo não interfere no comportamento ingestivo e bem-estar dos animais locados no sistema, assim como, a presença dos animais não interfere no desenvolvimento silvicultural das plantas.

PALAVRAS-CHAVES: Sistemas agroflorestais. Arranjo populacional. Comportamento ingestivo. Gado de corte.

\section{REFERENCES}

ALMEIDA, M. L. Desrama artificial em clones de híbridos de Eucalyptus grandis $\mathbf{x}$ E. urophylla com diferenças em arquitetura de copa. 2003. 119f. Dissertação (Mestrado em Ciência Florestal) - Universidade Federal de Viçosa, Viçosa, 2003.

ASSAD, M. L. L.; ALMEIDA, J. Agricultura e sustentabilidade: contexto, desafios e cenários. Ciência \& Ambiente. Santa Maria, n. 29, p. 15-30, 2004.

BARBOSA, O. R.; SILVA, R. G. Índice de conforto térmico para ovinos. Revista da Sociedade Brasileira de Zootecnia, Viçosa, v. 24, n. 6, p. 874-883, 1995.

FARIA, J. R.; SILVA, J. F.; NERIS, K. P.; LOPES, F. L. R.; SILVA, M. C.; LISBOA, E. S.; RODRIGUES, J.; CENTENO, A. J.; LOPES, F. M. Desenvolvimento de Eucaliptus urograndis no município de Corumbá-Go. Ensaios e Ciência: Ciências Biológicas, Agrárias e da Saúde, Campo Grande, v. 17, n. 2, p. 9-27, 2013.

FERREIRA, R. A. Maior produção com melhor ambiente para aves, suínos e bovinos. Viçosa, MG: Aprenda Fácil, 2005. 371p.

GLASER, F. D. Aspectos comportamentais de bovinos das raças Angus, Caracu e Nelore a pasto frente à disponibilidade de recursos de sombra e água para imersão. 2008, 117f. Tese (Doutorado - Faculdade de Zootecnia e Engenharia de Alimentos) - Universidade de São Paulo, Pirassununga, 2008.

INSTITUTO NACIONAL DE METEOROLOGIA - INMET/SEPAF/AGRAER/CEMTEC-MS. Banco de Dados: Centro de Monitoramento de Tempo, do Clima e dos Recursos Hídricos de Mato Grosso do Sul. Disponível em: <http://www.cemtec.ms.gov.br/?page_id=15>. Acesso em: nov. 2017.

KÖPPEN, W. Climatologia: con un estudio de los climas de la tierra. México: Fondo de Cultura Económica. 1948. 478p.

KRUSCHEWSKY, G. C.; MACEDO, R. L. G.; VENTURIN, N.; OLIVEIRA, T. K. de. Arranjo estrutural e dinâmica de crescimento de Eucalyptus spp. em sistema agrossilvipastoril no Cerrado. Cerne, Lavras, v. 13, n. 4, p.360-367, 2007. 
MACEDO, M. C. M. Integração lavoura e pecuária: o estado da arte e inovações tecnológicas. Revista Brasileira de Zootecnia, Viçosa, v. 38, p. 133-146, 2009. http://dx.doi.org/10.1590/S151635982009001300015

MARQUES FILHO, W. C.; BARBOSA, G. F.; CARDOSO, D. L.; FERREIRA, A. D.; PEDRINHO, D. R.; BONO, J. A. M.; SOUZA. C.C.; FRAINER, D. M. Productive sustainability in a silvopastoral system.

Bioscience Journal, Uberlândia, v. 33, n. 1, p. 10-18, 2017. http://dx.doi.org/10.14393/BJ-v33n1a2017-32925

OLIVEIRA, F.; MORENO, G.; LÓPEZ, L.; CUNHA, M. Origem, distribuição e funcões dos sistemas agroflorestais. Pastagens e Forragens, Elvas, v. 28, p. 93-115, 2007.

OLIVEIRA, T. K. de; MACEDO, R. L. G.; VENTURINI, N.; HIGASHIKAWA, E. M. Desempenho silvicultural e produtivo de eucalipto sob diferentes arranjos espaciais em sistema agrossilvipastoril. Pesquisa Florestal Brasileira, Colombo. v. 1, n. 60, p. 1-9, 2009. http://dx.doi.org/10.4336/2009.pfb.60.01

PACIULLO, D. S. C; LOPES, F. C. F.; MALAQUIAS JÚNIOR, J. D.; VIANA FILHO, A.; RODRIGUEZ, N. M.; MORENZ, M. J. F.; AROEIRA, L. J. M. Pasture traits and heifer performance in a silvipastoral system and in na exclusive Brachiaria pasture. Pesquisa Agropecuária Brasileira, Brasília, v. 44, n. 11, p. 1528-1535, 2009. http://dx.doi.org/10.1590/S0100-204X2009001100022

PERISSINOTO, M.; MOURA, D. J. de; MATARAZZO, S. V.; SILVA, I., J. O. da; LIMA, K., A. O. de. Efeito da utilização de sistemas de climatização nos parâmetros fisiológicos do gado leiteiro. Engenharia Agrícola, Jaboticabal, v. 26, n. 3, p. 663-671, 2006. http://dx.doi.org/10.1590/S0100-69162006000300002

PORFÍRIO-DA-SILVA, V.; MORAES, A.; MOLETTA, J. L.; PONTES, L. S.; OLIVEIRA, E. B.; PELISSARI, A.; CARVALHO, P. C. F. Danos causados por bovinos em diferentes espécies arbóreas recomendadas para sistemas silvipastoris. Pesquisa Florestal Brasileira, Colombo, v. 32, n. 70, p. 183-192, 2012. http://dx.doi.org/10.4336/2012.pfb.32.70.67

PORFÍRIO-DA-SILVA, V.; MEDRADO, M. J. S.; NICODEMO, M. L. F.; DERETI, R. M. Arborização de pastagens com espécies florestais madeireiras: implantação e manejo. Embrapa Florestas: Colombo - PR. 1 ed, p.10, 2009.

REINER, D. A.; SILVEIRA, E. R.; SZABO, M. S. O uso do eucalipto em diferentes espaçamentos como alternativa de renda e suprimento da pequena propriedade na região sudoeste do Paraná. Synergismus Scyentífica, Pato Branco, v. 6, n. 1, n.p. 2011.

SILVA, F. de A. S.; AZEVEDO, C. A. V. de. ASSISTAT software: statistical assistance. Versão 7.7 beta. Campina Grande: DEAG-CTRN-UFCG, 2014.

THUROW, J. M.; NABINGER, C.; CASTILHOS, Z. M. S.; CARVALHO, P.C. F.; MEDEIROS, C. M. O.; MACHADO, M. D. Estrutura da vegetação e comportamento ingestivo de novilhos em pastagem natural do Rio Grande do Sul. Revista Brasileira de Zootecnia, Viçosa, v. 38, n. 5, p. 818-826, 2009.

http://dx.doi.org/10.1590/S1516-35982009000500006

VARELLA, A. C.; SILVA, V. P.; RIBASKI, J.; SOARES, A. B.; MORAES, H.; SAIBRO, J. C.; BARRO, R. S. Estabelecimento de plantas forrageiras em sistemas de integração floresta-pecuária no Sul do Brasil. Passo Fundo - RS. 1 ed, p. 283-340. 2009.

VIEIRA, M.; VALDIR, M. Crescimento e produtividade de povoamentos monoespecíficos e mistos de eucalipto e acácia-negra. Pesquisa Agropecuária Tropical, Goiânia, v. 41, n. 3, p. 415-421, 2011. http://dx.doi.org/10.5216/pat.v41i3.10760 
ZANINE, A. M.; SANTOS, E. M.; FERREIRA, D. J. Grazing, leisure, rumination times and bite rate of bovine on pastures of different morphologic structures. Revista Eletrônica de Medicina Veterinária, Viçosa, v. 7, n. 1, p. 1-10, 2006. 